\title{
EFFECTS OF RAINFALL SHORTAGE AND CLIMATIC WATER BALANCE CHANGE ON AGRICULTURE
}

\author{
RADZKA, E. ${ }^{*}$ - JANKOWSKI, K. - JANKOWSKA, J. \\ Faculty of Natural Sciences, Siedlce University of Natural Sciences and Humanities \\ ul. Prusa14, 08-110 Siedlce, Poland \\ ${ }^{*}$ Corresponding author \\ e-mail: elzbieta.radzka@uph.edu.pl; phone:+48-25-643-1351 \\ (Received 11 $1^{\text {th }}$ Mar 2019; accepted $3^{\text {rd }}$ May 2019)
}

\begin{abstract}
This paper assesses of climatic water balance (CWB) in the 2000-2018 vegetation seasons and the rainfall requirements of selected crops. Extreme values and the range of variation for that time period are given emphasis to, paired with statistical significance of the slope of linear trends. The study found that the biggest difference in climatic water balance between 2018 and the 2000-2017 period was recorded in June $(29 \mathrm{~mm})$. Water shortages for cereals occurred in all months of the growing seasons both form 2000 to 2017 and in 2018, but in May 2018 water deficit was much larger than in the multiannual period. In the case of maize the last months of the 2018 growing season exhibited high deficiency of rainfall. For early potato varieties water shortages were not higher in 2018 than the average of the multiannual period. However, significant rainfall shortages for sugar beet were recorded in May and August 2018. In the 20002017 period the highest average monthly rainfall deficiencies for meadows and pastures were in July. In the same month there was also a statistically significant increase in the CWB value, on average, by about $6.4 \mathrm{~mm}$ per 10 years.
\end{abstract}

Keywords: precipitation, air temperature, drought, crops, Poland

\section{Introduction}

The ongoing climate change has a direct impact on agriculture. With the change of weather conditions, some factors determining plant yields such as requirements for agro technical practices and for fertilizer also change, together with incidence and severity of diseases and pests. The decisive factor shaping production systems in agriculture in the next few years, alongside climate change, may be the rising demand for food and competition for water. Climate change significantly increases the threat of drought (Sulewski and Czekaj, 2015), but for agriculture global warming may be sometimes beneficial as it opens the possibility of growing new varieties, not used earlier in some parts of the world (Gendron St-Marseille et al., 2019). Scientists predict that the trend in drought incidence in southern Europe and the North-Eastern part of South America will last up to 2050 (Ruane et al., 2018). The increasing frequency of droughts observed in recent years is a result of rising air temperature, lower than average rainfall, or even a complete lack of precipitation for a longer time (Górski, 2006; Kundzewicz et al., 2006; Łabędzki, 2006; Kozyra et al., 2009). Droughts cause significant yield losses (Łabędzki, 2006; Doroszewski et al., 2008). In the drought monitoring system (SMSR) in Poland, weather conditions causing water shortages in agriculture are measured by using climatic water balance (CWB) (Rojek, 1987; Kołodziej et al., 2003; Legates and Mccabe, 2005; Łabędzki, 2006; Kanecka-Geszke and Smarzyńska, 2007; Doroszewski et al., 2008). This period is referred to as agricultural drought (Niedźwiedź, 2003). The agricultural drought monitoring system has been developed on the basis of agro-meteorological studies 
(Doroszewski and Górski, 1995; Demidowicz et al., 1996, 1997; Doroszewski et al., 1997).

The aim of the research was to characterise climatic water balance and rainfall deficiency for selected crops in eastern Poland in 2018 compared to the 2000-2017 period. Attention was drawn to extreme values and variation range in that time series. Additionally, statistical significance of linear trend slopes was determined.

\section{Material and methods}

The analysis is based on the data recorded between 2000 and 2018 which was provided by the meteorological station in Siedlce $\left(\varphi^{\circ}=52^{\circ} 10^{\prime} 03^{\prime \prime} \mathrm{N} ; \lambda^{\circ}=22^{\circ} 17^{\prime} 24^{\prime \prime} \mathrm{E} ; 150 \mathrm{~m}\right.$ above sea level).

The following meteorological elements were analysed:

- daily mean air temperature.

- daily total precipitation.

- daily mean relative humidity.

The basic characteristics of the distribution of the tested parameters were determined: their arithmetic means, and minimum, and maximum values. To present the dynamics of monthly arithmetic means the coefficient of variation was calculated (Eq.1).

$$
\mathrm{V}=\frac{\mathrm{s}}{\mathrm{X}} * 100 \%
$$

where:

$\mathrm{CV}$ - coefficient of variation,

$\mathrm{SD}$ - standard deviation,

$\mathrm{X}$ - arithmetic mean.

Then evaporation was calculated using Ivanov's equation (Przedpełska, 1971) (Eq.2).

$$
E=0.0018(25+t)^{2}(100-f)
$$

where:

$\mathrm{t}$ - mean monthly air temperature, ${ }^{\circ} \mathrm{C}$,

$\mathrm{f}$ - mean monthly relative humidity, $\%$.

Monthly values of climatic water balance were designated using the following formula (Eq.3):

$$
\mathrm{CWB}=\mathrm{P}-\mathrm{E}
$$

where:

$\mathrm{P}$ - monthly sum of precipitation ( $\mathrm{mm})$,

$\mathrm{E}$ - monthly evaporation ( $\mathrm{mm})$.

Water needs of selected crops were estimated based on optimal precipitation according to the method specified by Klatt (after Nyc, 2006) (Eq.4).

$$
\text { Popt }=\mathrm{Pk}+5 * \mathrm{tk}
$$

where: 
Popt - optimal precipitation ( $\mathrm{mm})$,

$\mathrm{Pk}$ - optimal monthly precipitation according to the Klatt table (mm),

tk - mean monthly air temperature $\left({ }^{\circ} \mathrm{C}\right)$ for which Klatt determined the optimal precipitation $(\mathrm{Pk})$,

Shortages of rainfall were calculated according to the formula (Eq.5):

$$
\mathrm{N}=\operatorname{Prz}-\text { Popt }
$$

where:

$\mathrm{N}$ - precipitation deficit ( $\mathrm{mm})$,

Prz - recorded precipitation $(\mathrm{mm})$,

Popt - optimal precipitation according to Klatt (mm).

Water shortages were calculated for the following crops: spring wheat, oats, corn, early potato, sugar beet, meadows and pastures.

The values of the analyzed meteorological parameters, climatic water balance, and precipitation deficit in 2018 were compared to the values for the 2000-2017 period. The direction and significance of the trend of climatic water balance changes were established on the basis of the linear trend equation. The significance of the slope of the trend was assessed with Student's t-test with a significance level of $\alpha=0.05$.

\section{Result analysis and discussion}

The greatest average monthly precipitation during the 2000-20017 period was in July (72 mm), and the smallest in October and April with $37 \mathrm{~mm}$ and $38 \mathrm{~mm}$, respectively (Table 1). The minimum value of this parameter was noted in October (only $2 \mathrm{~mm}$ ), and the maximum in August $(257 \mathrm{~mm})$. Precipitation in October had the largest variation with the $\mathrm{CV}$ of $93 \%$. The first half of the growing season (April, May, June and July) exhibited around a $50 \%$ monthly variability of rainfall.

Table 1. Average mean, maximum, and minimum values of some meteorological parameters, with the coefficient of variation in Siedlce during the 2000-2017 period

\begin{tabular}{c|c|c|c|c|c|c|c|c}
\hline \multicolumn{2}{c|}{ Parameter/Month } & April & May & June & July & August & September & October \\
\hline \multirow{4}{*}{$\begin{array}{c}\text { Precipitation } \\
(\mathrm{mm})\end{array}$} & Mean & 38 & 60 & 64 & 72 & 66 & 53 & 37 \\
& Max & 82 & 138 & 166 & 180 & 257 & 165 & 130 \\
& Min & 6 & 22 & 18 & 9 & 12 & 14 & 2 \\
Air temperature & CV & 53 & 52 & 56 & 53 & 81 & 78 & 93 \\
$\left({ }^{\circ}\right.$ C) & Mean & 8.6 & 13.9 & 16.6 & 19.2 & 18.5 & 13.5 & 8.2 \\
& Max & 12.1 & 16.7 & 18.3 & 21.8 & 20.8 & 15.7 & 10.8 \\
& Min & 6.2 & 11.3 & 14.2 & 16.4 & 16.8 & 11.3 & 5.1 \\
Relative & CV & 16.0 & 9.9 & 7.1 & 7.2 & 5.5 & 9.2 & 21.1 \\
humidity (\%) & Mean & 69.5 & 71.2 & 72.6 & 73.9 & 74.2 & 80.2 & 83.5 \\
& Max & 80.0 & 84.9 & 83.2 & 85.5 & 83.1 & 88.7 & 93.8 \\
& Min & 61.5 & 62.0 & 63.2 & 57.6 & 59.1 & 68.7 & 76.2 \\
& CV & 7.7 & 7.7 & 8.0 & 8.2 & 7.4 & 6.6 & 5.5 \\
\hline \multirow{5}{*}{ CWB (mm) } & Mean & -64 & -79 & -86 & -91 & -89 & -54 & -32 \\
& Max & -40 & -38 & -44 & -44 & -54 & -23 & -9 \\
& Min & -85 & -109 & -124 & -168 & -156 & -92 & -53 \\
& CV & 20 & 23 & 25 & 28 & 25 & 33 & 34 \\
\hline
\end{tabular}


The warmest month in the 2000-2017 period was August with the average air temperature of $18,5^{\circ} \mathrm{C}$, while October with $8.2^{\circ} \mathrm{C}$ was the coldest. In the same month the minimum value of this parameter was recorded $\left(5.1^{\circ} \mathrm{C}\right)$, while the largest $\left(21.8^{\circ} \mathrm{C}\right)$ was in July. The largest variation of the monthly average temperature was in October $(\mathrm{CV}=$ $21.1 \%)$ and the lowest in August $(\mathrm{CV}=5,4 \%)$.

The observed trend of rising temperature and changing evaporation conditions increased the area of the moderately dry region in Poland from 13\% in the 1931-1960 period to $20 \%$ in the $1971-2000$ period, and the area of land with high soil moisture decreased from 32\% to 10\% (Ziernicka-Wojtaszek, 2009).

Average relative air humidity in the growing season varied from $69.5 \%$ in April to $83.5 \%$ in October. The maximum value for this parameter was noted in October $(93.8 \%)$, and the minimum in July $(57.6 \%)$. The variability of humidity ranged from $5.5 \%$ in October to $8.2 \%$ in July. The average monthly values of the climatic water balance in the 2000-2017 growing seasons were negative. The maximum value of this parameter was noted in October $(-9 \mathrm{~mm})$ and minimum in July $(-168 \mathrm{~mm})$, while CWB variation remained at around $27 \%$.

Multiannual average rainfall (2000-2017) in the growing season was $390 \mathrm{~mm}$, and in 2018 it was $347 \mathrm{~mm}$, which was only about $43 \mathrm{~mm}$ less (Fig. 1). However, monthly sums of precipitation were slightly larger than the multiannual average only in April, June, and July 2018 (Fig. 1). Compared to the average in May 2018 rainfall was lower by $34 \mathrm{~mm}$, in August by about $37 \mathrm{~mm}$, in September by $11 \mathrm{~mm}$, and in October by $3 \mathrm{~mm}$.

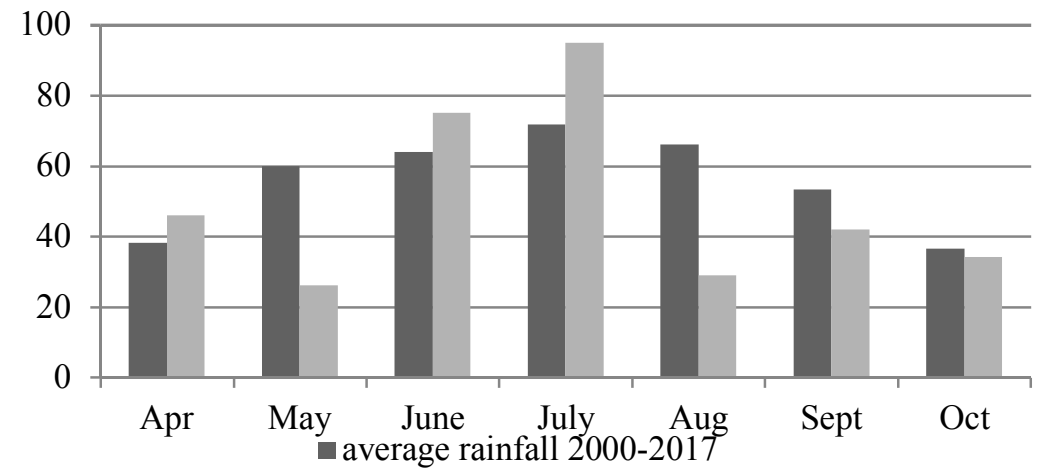

Figure 1. Average monthly rainfall $(\mathrm{mm})$ of the 2000-2017 period and in 2018 in Siedlce

It was found that in all months of the 2018 growing season the average monthly air temperature was higher than the average multiannual (Fig. 2). In April 2018 it was higher than the average multinational by $4^{\circ} \mathrm{C}$. The smallest difference in thermal conditions between 2018 and the multiannual period was in July, with the temperature in 2018 higher by only $0.3^{\circ} \mathrm{C}$.

Changes in relative air humidity in 2018 were inverse to changes in air temperature (Fig. 3). In all the months of the 2018 growing season, with the exception of July, the value of this parameter was a few percent less than the multiannual average.

Similarly, the values of climatic water balance in July 2018 were $7 \mathrm{~mm}$ higher than the multiannual average (Figs. 4 and 5). In the remaining months of the 2018 growing season precipitation shortage was bigger than the perennial values, and the biggest difference was recorded in June (29 $\mathrm{mm})$. 
Using the Penman-Monteith equation Łabędzki et al. (2012) found that the average evapotranspiration in Poznań, Olsztyn, and Cracow ranged from 50-60 mm in April and September to $100-120 \mathrm{~mm}$ in the remaining months of the growing season. The largest value of evapotranspiration in those areas was in July.

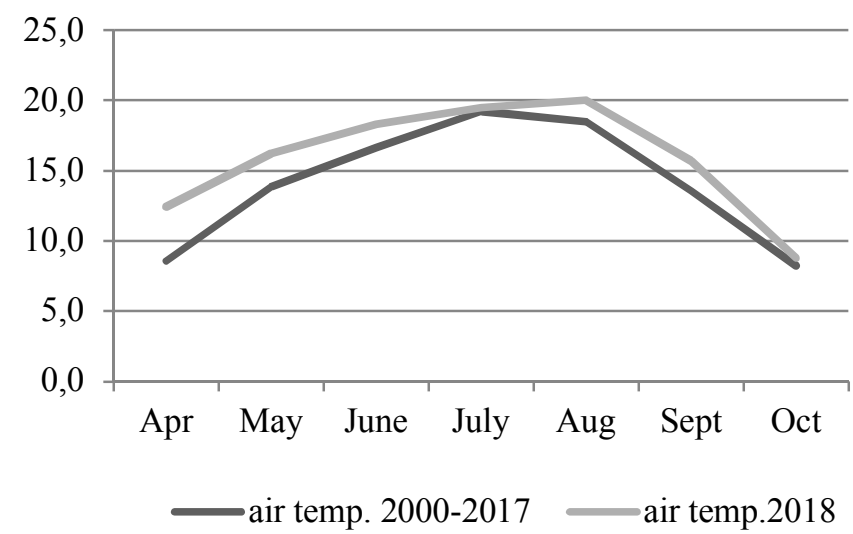

Figure 2. Average monthly air temperature $\left({ }^{\circ} \mathrm{C}\right)$ in the 2000-2017 period and in 2018 in Siedlce



—realitive humidity $2000-2017$

Figure 3. Average monthly relative humidity (\%) in 2000-2017 and in 2018 in Siedlce

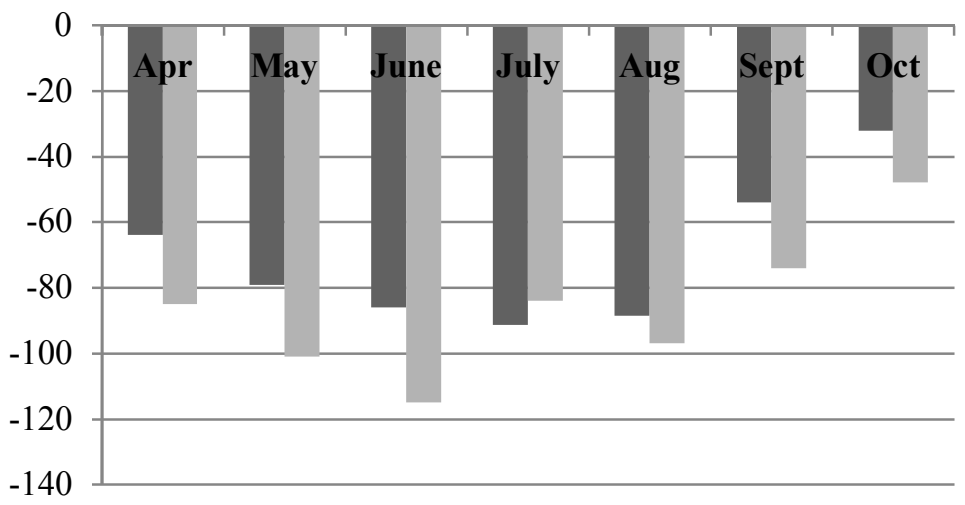

- KBW 2000-2017

Figure 4. Average monthly climatic water balance $(\mathrm{mm})$ in the 2000-2017 period and in 2018 in Siedlce 


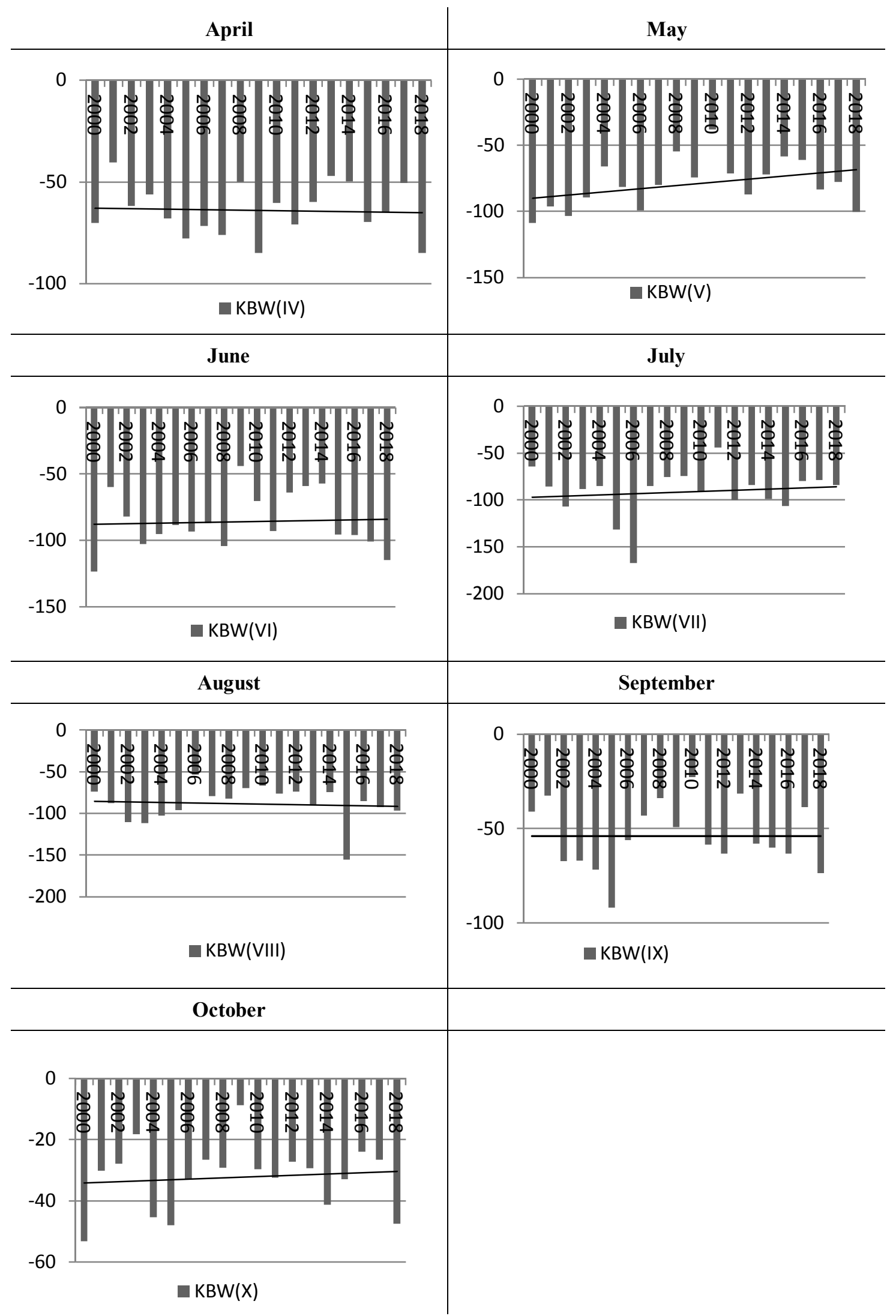

Figure 5. Climatic water balance ( $\mathrm{mm}$ ) and linear trend in the 2000-2018 vegetation seasons in Siedlce 
Projected climate change (Watson et al., 1997; Stuczyński et al., 2000) justifies the need for the current monitoring of the incidence and extent of drought. A prolonged lack of precipitation and resulting evapotranspiration processes reduce agricultural productivity. Agricultural drought seriously reduces plant growth, which leads to a significant drop in crop yields. A longer period of reduced precipitation leads to soil drought (Łabędzki, 2007; Vicente-Serrano et al., 2010). Changes in both precipitation and air temperature affect climatic water balance. In 2018 agricultural drought occurred in Poland for all monitored plants in all provinces with 1923 communes affected, which constituted $49 \%$ of agricultural land. Analysis of the linear trend of climate change impact on water balance showed that slope values were positive only in May, June, and July (Table 2). Furthermore, it was found that in July there was a statistically significant increase in the CBW value, on average, by about $6.4 \mathrm{~mm}$ in 10 years. However, in the rest of the growing season there was a declining tendency, but it was not statistically significant. Changes in the structure of water balance led to water deficit which significantly affected the level of plant production and changes in the structure of crop production.

Table 2. Linear regression of climatic water balance changes in 2000-2018 in Siedlce

\begin{tabular}{c|c}
\hline Month & Linear regression \\
\hline April & $\mathrm{y}=-0.136 \mathrm{x}+210.95$ \\
May & $\mathrm{y}=1.214 \mathrm{x}-2518.42$ \\
June & $\mathrm{y}=0.202 \mathrm{x}-491.27$ \\
July & $\mathrm{y}=0.637 * \mathrm{x}-1370.89$ \\
August & $\mathrm{y}=-0.372 \mathrm{x}+658.52$ \\
September & $\mathrm{y}=-0.005 \mathrm{x}-43.32$ \\
October & $\mathrm{y}=-0.005 \mathrm{x}-43.32$ \\
\hline
\end{tabular}

By analyzing the 1970-2010 period Łabędzki et al. (2012) found that in Poland there had been a significant statistically significant increase of total evapotranspiration in the growing seasons (April-September). There was a change in the temporal distribution of rainfall, with an increase in the amount of precipitation during the winter and early spring, and a decrease in spring and summer. This reduced climatic water balance, with an increase in rainfall shortage in relation to potential evaporation. Especially in recent years, spring and early summer climatic water balance values have been getting smaller, which means that periods of drought are becoming more and more severe. This coincides with the period of greatest water requirements of crops, especially of cereals. The manifestation of water scarcity trends was the extreme drought of 2018, resulting in the average yield of certain crops decreasing by up to $30 \%$ in Poland.

In all months of the 2018 growing season there were water shortages for the analyzed cereals (Fig. 5). When compared to the average multinational values it was found that they were the biggest in May. For wheat and oats the shortage of rainfall in the same month was $55 \mathrm{~mm}$, and it was larger than the multiannual value by $28 \mathrm{~mm}$. For maize it was $40 \mathrm{~mm}$ and surpassed the perennial average by $17 \mathrm{~mm}$.

Demand for water is related to the species and its stage of growth and development. It increases as the weight of the fresh matter and transpiration increase. The greatest demand for water is usually during the critical period in plant development. This corresponds to the end of vegetative development and the beginning of the formation of generative organs. The critical period for cereals is during the following stages: stem formation, 
heading, and grain development and filling (Chmura et al., 2009). Spring wheat reacts to shortage and excess of water particularly adversely during tillering and stem formation. Rain excess causes extension of the growing season, delays maturity, increases the incidence of disease, and it can cause sprouting during the harvest. Dmowski et al. (2008) found that sufficient rainfall in April and May is conducive to germination and tillering, and in June to the formation of the main shoot, side shoots, and grain development. Moderate rainfall in July is conducive to further grain filling and grain maturing on the main and side shoots. Research of Zagdańska and Wiśniewski (2001) has shown that the ability of spring wheat to increase its resilience (acclimatization) under the influence of the previously occurring drought is a varietal characteristic. Among cereals, oat is distinguished by its low resistance to drought due to a high transpiration rate and lower water use efficiency (Anderson and Mc Lean, 1989; Wojcieska, 1993). Considering the frequent occurrence of the shortage of rainfall in the most recent period in Poland, it can be assumed that drought negatively affects not only the yield of oats but also grain quality.

In the case of maize the last months of the 2018 growing season (August and September) also exhibited high water deficiency. In August that year the shortage was 58 $\mathrm{mm}$, and in September it reached as much as $73 \mathrm{~mm}$. Deficiencies in these months exceeded multiannual values by $22 \mathrm{~mm}$ and $48 \mathrm{~mm}$. A lack of water during the growing season for maize causes uneven growth and development of plants, and withering in extreme cases (Dudek et al., 2009). According to Stuczyński et al. (2000) despite the prevailing water scarcity the importance of maize in Poland will increase, and it will become the primary spring cereal.

In the case of early potato varieties water shortages in 2018 were not higher than the average multiannual. The critical period of potato plants is during the following stages: flower bud formation, flowering, tuber formation, and leaf yellowing. In the period from planting to shoot formation, the potato plant uses water supplies stored in the parent tuber. During the time from shooting to flower bud formation water needs are also small. From flower bud formation onwards water needs regularly increase (Chmura et al., 2009). Varieties of early potatoes respond to water shortages especially negatively (Rykaczewska, 2007) because of an intense increase in the mass of above-ground parts and fast growth of tubers (Wheeler et al., 2003; Smith, 2006).

For sugar beet significant rainfall shortages were in May and August 2018, with $40 \mathrm{~mm}$ in the former and $73 \mathrm{~mm}$ in the latter. In the remaining months of the growing season that year they were not higher than average values for the 2000-2017 period. Sugar beet has the greatest sensitivity to a lack of soil moisture in the initial period, and later, especially after the end of August, dry and warm weather is more favourable, increasing its quality (Svachula and Pulkrabek, 2000). The critical stage of sugar beet lasts about 60 days when the leaf canopy covers the ground and during the intense thickening of the root (Chmura et al., 2009).

For meadows and pastures the highest average monthly rainfall deficiency with $43 \mathrm{~mm}$ and $-53 \mathrm{~mm}$, respectively, occurred in July of the 2000-2017 period (Fig. 6). On the other hand, in July 2018 shortages were the smallest ( $-5 \mathrm{~mm}$ for meadows and $-15 \mathrm{~mm}$ for pastures). It was found that the greatest shortage of rainfall in 2018 was in May (-55 $\mathrm{mm}$ for meadows, and $-60 \mathrm{~mm}$ for pasture) and in August (-68 $\mathrm{mm}$ for meadows and pastures). In the remaining months of the 2018 growing season water deficit was smaller than the average multiannual. Meadow water needs are different for each of the growth cycles. 




Figure 6. Average monthly rainfall shortages $(\mathrm{mm})$ for selected crops during the 2000-2018 period and in 2018 in Siedlce 
The greatest demand for water is during the second one, i.e. in June and July. Grabarczyk (1989) found that, depending on the region, water needs in the first growth cycle are $125-158 \mathrm{~mm}, 186-240 \mathrm{~mm}$ in the second, and $160-190 \mathrm{~mm}$ in the third. On pastures when vegetation becomes yellowish and there is no biomass increase, grazing should stop until grass regenerates after rainfall. Such regeneration should last at least 3 weeks. Kasperska-Wołowicz (2007) points out that the most common instances of insufficient moisture in meadows and pastures can be expected in August. Leśny and Juszczak (2005) report that both in dry and wet growing seasons in grassland areas most winter precipitation surplus evaporates in May. Insufficient rainfall and increasing grassland dryness often lead to very large and adverse changes in both soil and plants. Stuczyński et al. (2000) argue that the period of animals grazing will significantly increase, although in summer it can be inefficient due to periodic droughts.

\section{Conclusions}

Values of climatic water balance in July 2018 were $7 \mathrm{~mm}$ higher than the multiannual average. In the remaining months of the 2018 growing season precipitation shortage was bigger than the average values of the 2000-2017 period. The biggest difference in climatic water balance between 2018 and the multinational was recorded in June ( $29 \mathrm{~mm}$ ). It was found that in July there was a statistically significant increase in the value of CWB, on average, of about $6.4 \mathrm{~mm}$ per 10 years. For analysed cereals water shortages occurred in all months of the growing season both in 2000-2017 and in 2018. In May 2018 deficits were much larger than the average perennial value. In the case of maize the last months of the 2018 growing season (August and September) also exhibited high deficiency of rainfall. An important solution will be suitable agricultural practices that can mitigate the effects of drought. Earlier varieties of plants with the period of greatest demand for water before strong droughts will be introduced. For early potato varieties water shortages in 2018 were not higher than the average multinational. However, significant rainfall shortages for sugar beet were in May and August 2018. Those deficiencies were well above the critical values and could have resulted in a decline in the level of crop yield and deterioration of the quality of raw material. For meadows and pastures the highest average monthly rainfall deficiencies in the 2000-2017 period occurred in July (-43 mm for meadows and -53 pastures). In 2018 the greatest shortage of rainfall was recorded in May (-55 $\mathrm{mm}$ for the meadows and $-60 \mathrm{~mm}$ for pastures) and in August (-68 mm both for meadows and pastures).

Drought causes withering and significant loss of some fodder species; forage on meadows should be harvested earlier because in drought conditions its quality worsens every day. Changes of water balance basic components occurring in temperate latitudes are a result of an increase in air temperature and evaporation. An increase in the air temperature with unchanging annual total precipitation can cause water shortages lowering crop yields, especially on sandy soils with poor retention. It can be inferred from the present analysis that the composition of crop species should be adapted to changing climatic conditions. The studies indicate that a drought should be monitored to assess its impact on crops. Persistent unfavourable weather conditions lasting for a longer time may determine the choice of plant species to be grown in the region. Additionally, by designating areas that are particularly vulnerable to the effects of droughts it is possible to carry out a more complete assessment of the impact of climate change on agriculture in Europe. 


\section{REFERENCES}

[1] Anderson, W. K., Mc Lean, R. (1989): Increased responsiveness of short oat cultivars to early sowing, nitrogen fertilization and seeding rate. - Aust. J. Agric. Res. 40: 729-744.

[2] Chmura, K., Chylińska, E., Dmowski, Z., Nowak, L. (2009): Role of the water factor in yield formation of chosen field crops. - Infrastructure and Ecology of Fural Areas 9: 3344.

[3] Demidowicz, G., Doroszewski, A., Górski, T. (1996): The impact of rainfall shortages on potato and sugar beet production losses. - Zeszyty Problemowe Postępów Nauk Rolniczych. Iss. 438: 43-52. (in Polish).

[4] Demidowicz, G., Doroszewski, A., Górski, T. (1997): Methodology of the estimation of agricultural production losses caused by rainfall deficit. - Roczniki AR w Poznaniu. T. 291. Melioracje i Inżynieria Środowiska. Iss. 17: 233-243. (in Polish).

[5] Dmowski, Z., Dzieżyc, H., Nowak, L. (2008): The assessment of the impact of selected parameters - precipitation and soil - on the spring wheat yield in South-Western Poland. Acta Agrophysica 11(3): 613-622. (in Polish).

[6] Doroszewski, A., Górski, T. (1995): A simple coefficient of potential evapotranspiration. - Roczniki AR w Poznaniu. Vol. 271. Melioracje i Inżynieria Środowiska. Iss. 16: 3-8. (in Polish).

[7] Doroszewski, A., Kozyra, J., Pudełko, R., Stuczyński, T., Jadczyszyn, J., Koza, P., Łopatka, A. (2008): Monitoring of agricultural drought in Poland. - Wiadomości Melioracyjne i Łąkarskie. Iss. 1: 35-38. (in Polish).

[8] Dudek, S., Żarski, J., Kuśmierek-Tomaszewska, R. (2009): Results of a multiannual field experiment on maize response to irrigation. - Infrastruktura i Ekologia Terenów Wiejskich, Iss. 3: 167-174. (in Polish).

[9] Górski, T. (2006): The variation of agroclimatic conditions and the length of the growing period in the last century. - In: Gutry-Korycka, M., Kędziora, A., Starkel, L., Ryszkowski, L. (eds.) Long-term transformation of Polish landscape as a result of changes in climate and land use. Poznań. Joint publication. IGBP Komitet Narodowy: 65-77. (in Polish).

[10] Grabarczyk, S. (1989): Water needs of grassland and grass. - Zesz. Probl. Postępów Nauk Rol. Z 343: 43-55. (in Polish).

[11] Kanecka-Geszke, E., Smarzyńska, K. (2007): Evaluation of meteorological drought with a variety of indexes in selected agroclimatic regions of Poland. - Acta Scientiarum Polonorum. Formatio Circumiectus. Iss. 6. Z. 2: 41-50. (in Polish).

[12] Kasperska-Wołowicz, W. (2007): Water shortages of meadows on peat-muck soil in different agroclimatic regions of Poland. - Acta Agrophysica 9(3): 645-655. (in Polish).

[13] Kołodziej, J., Liniewicz, K., Bednarek, H. (2003): Precipitation in the Lublin area and water requirements of crops. - Annales UMCS. Sect. E. Vol. 58: 101-110. (in Polish).

[14] Kozyra, J., Doroszewski, A., Nieróbca, A. (2009): Climate change and its expected impact on agriculture in Poland. - Studia i Raporty IUNG-PIB. Puławy. Iss. 14: 243-257. (in Polish).

[15] Kundzewicz, Z., Szwed, M., Radziejewski, M. (2006): Climate change and extreme hydrological phenomena: floods and droughts. - In: Gutry-Korycka, M., Kędziora, A., Starkel, L., Ryszkowski, L. (eds.) Long-term transformation of Polish landscape as a result of climate and land use change. Joint publication. Komitet Narodowy IGBP: 169-180. (in Polish).

[16] Labędzki, L. (2006): Agricultural drought - an outline of the problem. Methods of monitoring and classification. - Woda Środowisko Obszary Wiejskie. Rozprawy Naukowe Monografie. Iss. 17: 107. (in Polish).

[17] Łabędzki, L. (2007): Estimation of local drought frequency in central Poland using the standardized precipitation index SPI. - Irrigation and Drainage 56(1): 67-77.

[18] Łabędzki, L., Bąk, B., Kanecka-Geszke, E. (2012): The size and variability of transpiration coefficient according to Penman-Monteith in the 1970-2004 growing periods in selected 
regions of Poland. - Woda-Środowisko-Obszary Wiejskie. Vol. 12. Iss. 2(38): 159-170. (in Polish).

[19] Legates, D. R., Mccabe, G. J. (2005): A re-evaluation of the average annual global water balance. - Physical Geography 26: 467-479.

[20] Leśny, J., Juszczak, R. (2005): Atmospheric water balance in agricultural and woodland areas. - Woda, Środ. Obsz. Wiej. 5, 2(15): 53-65. (in Polish).

[21] Niedźwiedź, T. (2003): A dictionary of weather. - Seria Atlasy i Monografie IMGW. Warszawa. PTGeof. ISBN 83-88897-25-X pp. 496. (in Polish).

[22] Nowak, L. (2006): Irrigation of root crops. - In: Karczmarczyk, S., Nowak, L. (eds.) Irrigation of crops. Joint publications. Poznań. PWRiL: 368-372. (in Polish).

[23] Nyc, K. (2006): The introduction of irrigation systems. - In: Karczmarczyk, S., Nowak, L. (eds.) Irrigation of crops. PWRiL, Poznań, chapter 7: 157-174. (in Polish).

[24] Przedpełska, W. (1971): The issue of atmospheric drought in Poland and methods of its determination. - Prace PIHM. Iss.103: 3-27. (in Polish).

[25] Rojek, M. (1987): Temporal and spatial distribution of climatic and agroclimatic water balance in Poland. - Zeszyty Naukowe AR we Wrocławiu. Z. 62 pp. 68. (in Polish).

[26] Rykaczewska, K. (2007): Comparison of the productivity of several early potato varieties, domestic and foreign. - Zeszyty Problemowe Postępów Nauk Rolniczych. Iss. 517: 629638. (in Polish).

[27] St-Marseille, A. F. G., Bourgeois, G., Brodeur, J., Mimee B. (2019): Simulating the impacts of climate change on soybean cyst nematode and the distribution of soybean. - Agricultural and Forest Meteorology 264: 178-187.

[28] Stuczyński, T., Demidowicz, G., Deputat, T., Górski, T., Krasowicz, S., Kuś, J. (2000): Adaptation scenarios of future climate change. - Environmental Monitoring and Assessment 61: 133-144.

[29] Sulewski, P., Czekaj, S. (2015): Climate and institutional change and projected economic performance of Polish farms. - Szkoła Główna Gospodarstwa Wiejskiego Warszawa. DOI: 10.5604/00441600.1146932. (in Polish).

[30] Svachula, V., Pulkrabek, J. (2000): Dependence of betaine content in sugar beet on the rainfall and air temperature during the vegetation. - Rostl. Vyroba no 46(2): 77-80.

[31] Vicente-Serrano, S., Begueri'a, S., Lo'pez-Moreno, J. (2010): A Multiscalar Drought Index Sensitive to Global Warming: The Standardized Precipitation Evapotranspiration Index. Journal of Climate 23: 1696-1718.

[32] Watson, R. T, Zinyowera, M. C., Moss, R. H., Dokken, D. J. (1997): IPCC The regional impact of climate change: IPCC special report on the regional impacts of climate change. - An assessment of vulnerability [online].

[33] Wiśniewski, K., Zagdańska, B. (2001): Genotype-dependent proteolytic response of spring wheat to water deficiency. - J. Exp. Bot.: 1455-1463.

[34] Wojcieska, U. (1993): Oat physiology. - In: Puławy, I. (ed.) Oat biology and agriculture. R(304): 53-94. (in Polish). 